\title{
Neurotransmitters in hiccups
}

CrossMark

\author{
Fauzia Nausheen ${ }^{1}$, Hina Mohsin ${ }^{2}$ and Shaheen E. Lakhan ${ }^{1,2^{*}}$
}

\begin{abstract}
Hiccups are the sudden involuntary contractions of the diaphragm and intercostal muscles. They are generally benign and self-limited, however, in some cases they are chronic and debilitating. There are approximately 4000 admissions for hiccups each year in the United States. The hiccup reflex arc is composed of three components: (1) an afferent limb including the phrenic, vagus, and sympathetic nerves, (2) the central processing unit in the midbrain, and (3) the efferent limb carrying motor fibers to the diaphragm and intercostal muscles. Hiccups may be idiopathic, organic, psychogenic, or medication-induced. Data obtained largely from case studies of hiccups either induced by or treated with medications have led to hypotheses on the neurotransmitters involved. The central neurotransmitters implicated in hiccups include GABA, dopamine, and serotonin, while the peripheral neurotransmitters are epinephrine, norepinephrine, acetylcholine, and histamine. Further studies are needed to characterize the nature of neurotransmitters at each anatomical level of the reflex arc to better target hiccups pharmacologically.
\end{abstract}

Keywords: Hiccup, Neurotransmitters, Therapies

\section{Background}

The term "singultus" (hiccup) comes from singult; a Latin word that means 'sob' or 'gasp'. It refers to the sounds that are produced by the sudden involuntary contractions of the diaphragm and intercostal muscles followed by an abrupt contraction of the glottis. The air strikes the closed glottis and results in the characteristic "hiccup" sound. Hiccups are usually benign and self-limiting. They generally start without any specific reason and disappear in a few minutes. Brief episodes of hiccups are common in healthy individuals after a large meal, intake of alcoholic beverages, or sudden excitement.

This article provides a review of different neurotransmitters that are related in the mechanism of action of the most commonly used drugs to treat hiccups, and the medications that induced hiccups. At the end, this paper draws a conclusion about the neurotransmitters involved in the pathophysiology of hiccups.

\footnotetext{
*Correspondence: slakhan@gnif.org

1 Department of Medical Education, California University of Science and Medicine - School of Medicine, 1405 W. Valley Blvd, Suite 101, Colton, CA 92343, USA

Full list of author information is available at the end of the article
}

\section{Epidemiology}

The classification of hiccups is based on their duration. An acute attack lasts less than forty-eight hours. Persistent hiccups last more than 2 days. Intractable hiccups are present if the attack lasts more than 1 month. Persistent hiccups are most likely to be associated with an underlying pathological, anatomic or organic disease process (Cymet 2002). Intractable hiccups that continue for more than 1 month are usually indicative of a serious organic disturbance (Vaidya 2000). If left untreated, intractable hiccups can cause severe discomfort, depression, reduced physical strength, and even death (Consults 2011). According to a report by William H. Dobelle, approximately 4000 hospital admissions due to hiccups are reported each year in the United States (Dobelle 1999). The intractable hiccups are more common in men $(82 \%)$ than in women. Most of the men suffering from hiccups are 50 years of age or older (Cymet 2002). Psychogenic hiccups have been reported to occur more commonly in women. The usual rate for hiccups is four to sixty per minute with fairly constant frequency in an individual (Howes 2012). Pathological hiccups can be explained as a form of epilepsy or a failure of supra-spinal inhibition (Launois et al. 1993; Lewis 1985). The incidence and prevalence of persistent and intractable hiccups in the community has not been studied. 


\section{Pathophysiology}

The pathophysiological mechanism of hiccups is related to lesions in its reflex arc as shown in Fig. 1. The reflex arc is comprised of three components:

1. The afferent limb including phrenic, vagus, and sympathetic nerves to pass on somatic and visceral sensory signals;

2. The central processing unit in the midbrain; and

3. The efferent limb travelling in motor fibers of phrenic nerve to diaphragm and accessory nerves to the intercostal muscles, respectively.

The central component is located in the periaqueductal grey, subthalamic nuclei (Hansen and Rosenberg 1993) among the brain stem respiratory center, phrenic nerve nuclei, reticular formation and hypothalamus. The central component for hiccups lies in the medulla and is thought to be entirely separate from the pathways involved in rhythmic breathing (Davis 1970). Dopamine, gamma-amino-butyric-acid (GABA), serotonin, glutamate, and glycine neurotransmitters can regulate this central mechanism. The hiccup arc has modulatory input from catecholaminergic and serotonergic afferents.

The release of 5-hydroxyl-tryptamine (5HT) from the gut enterochromaffin cells and enteric vagal afferents may also lead to hiccups as seen in a case report following administration of cisplatinum, a chemotherapeutic agent (Jatoi 2009). The mental branch of the trigeminal nerve was also postulated to develop hiccups when stimulated via chin shaving (Todisco et al. 2004). Significant negative intrathoracic pressure may occur during hiccups that may result in hypotension, bradycardia, pneumomediastinum, and subcutaneous emphysema (Rousseau 1995). The mechanism of action of hiccups might be mediated through agonizing 5-HT1A and antagonizing 5-HT2A receptors to enhance the activity of the phrenic nerve, thereby inducing hiccups. This concept was supported in

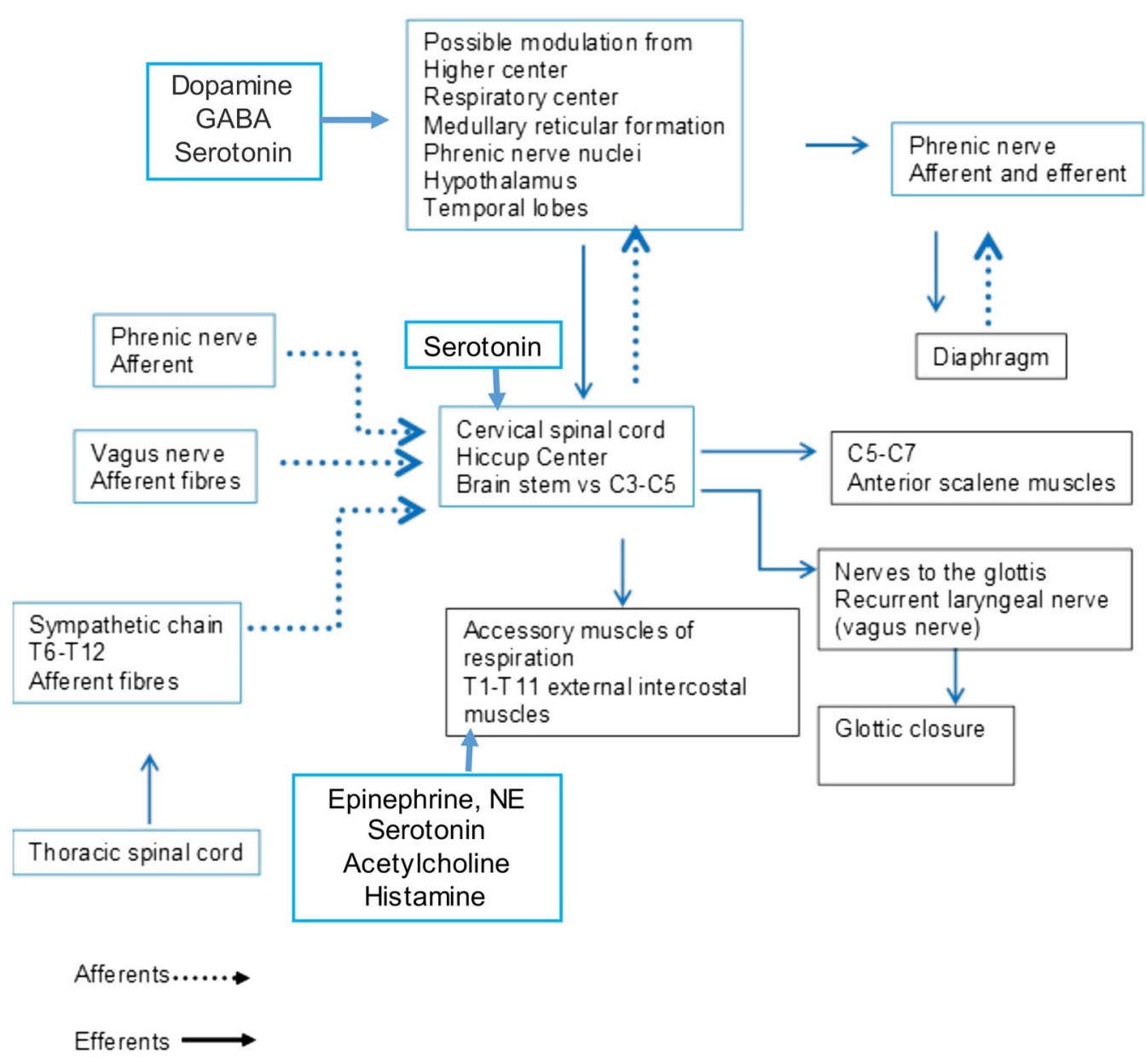

Fig. 1 Hiccup reflex arc with neurotransmitters 
a case report in which quetiapine was successfully used to resolve the aripirazole-induced hiccups. This may suggest the partial agonist and relatively high 5-HT1A receptors binding affinities in the pathophysiology of hiccups (Gilson and Busalacchi 1998). It is postulated in a study that the GABA-containing cells in the nucleus raphe are the source of GABA-nergic inhibition of the hiccup center (Musumeci et al. 2000).

The most commonly used pharmacological treatments include metoclopramide which reduces the intensity of esophageal contraction, chlorpromazine (Twycross et al. 2002), baclofen, nifedipine which reverses the abnormal depolarization in the hiccups reflex, valproic acid that enhances GABA transmission centrally (Smith and Busracamwongs 2003), antipsychotics, glucagon, GABA analogue which acts by activating an inhibitory neurotransmitter, and dimethlamine derivative of phenothiazine which acts centrally by dopamine blockade in the hypothalamus (Friedman 1996). Baclofen (GABA-agonist) is among the substances that act through the nervous system and has by far the best ability to treat chronic hiccups (Guelaud et al. 1995; Oshima et al. 1998; Petroianu et al. 1997; Steger et al. 2015). However, a Cochrane systemic review found insufficient evidence as to which pharmacological agent is best for hiccups (Moretto et al. 2013). Hiccups are the manifestation of diaphragmatic myoclonus and are considered to be a form of physiologic myoclonus.

\section{Etiology}

In the review of recent literature, a variety of hiccups etiologies have been reported (idiopathic, organic, psychogenic, and medication-induced) induced have been reported. Table 1 provides an overview of pathology that has been reliably linked to this condition. It has been suggested that damage to the cervical cord, brainstem, hypothalamus, and supra-tentorial area precipitate hiccups by stimulating the hiccups reflex arc or decreasing the normal inhibition of hiccup neurons. It is suggested that all potentially successful therapeutic drugs used to treat hiccups either decrease the input from gastrointestinal tract (GIT) to the hiccups center or decrease the excitability and output from the hiccups center (Burke et al. 1988; Petroianu et al. 1997).

\section{Neurotransmitters targets in hiccups}

The exact etiology of hiccups is unclear, and it is unknown why diverse drugs like dopamine blocking agents (DBA), baclofen, clonazepam, and phenytoin, which have widely varying mechanisms of action, can be effective in the treatment of hiccups (Peleg and Peleg 2000). Table 2 summarize drugs which induce and treat hiccups and their potential neurotransmitters.

\section{Gama-amino butyric acid (GABA)}

There is strong evidence that the GABA is one of the neurotransmitters involved in the hiccups reflex at the central level. GABA functions as an inhibitory mediator at the interneuron level in the brain and in the spinal cord (presynaptic inhibition) by altering trans-membrane potential. Glutamic acid is decarboxylated to produce GABA by the enzyme L-glutamate decarboxylase (Rodwell 2012). The inhibition of synapses by GABA has been shown in the cerebellar cortex, hippocampus, olfactory bulb, cuneate nucleus, caudate nucleus, substantia nigra, septal nucleus, and between the vestibular and trochlear

Table 1 Common causes of hiccups

\begin{tabular}{|c|c|c|}
\hline \multirow[t]{5}{*}{ Central nervous system } & Vascular & Stroke, Infarct, SLE related vascular disorders and aneurysm \\
\hline & Infectious & Meningitis and Encephalitis \\
\hline & Structural & Brain injury, Intracranial tumors \\
\hline & Inflammation & Neuromyelitis optica and multiple sclerosis \\
\hline & Miscellaneous & Seizure, Parkinson's Syndrome \\
\hline $\begin{array}{l}\text { Peripheral Nervous System (phrenic, vagal } \\
\text { and sympathetic nerves) }\end{array}$ & Gastrointestinal & $\begin{array}{l}\text { Hiatus hernia, Esophageal cancer, Gastro-esophageal reflex } \\
\text { disease, stomach volvulus and H.pylori infection, Pancreatitis, } \\
\text { Abdominal abscess and Abdominal tumors }\end{array}$ \\
\hline \multirow[t]{2}{*}{ Thoracic } & Cardiovascular & Myocardial Ischemia, Pericarditis, Thoracic Aneurysm \\
\hline & Pulmonary & Bronchitis, Pneumonia, Asthma, Bronchial carcinoma, Tuberculosis \\
\hline Ear, Nose and Throat & & Rhinitis, Otitis, Pharyngitis, Foreign body in nose or ear \\
\hline \multirow[t]{3}{*}{ Other causes } & Toxic metabolic & $\begin{array}{l}\text { Electrolyte imbalance, Alcohol, Chronic renal failure, Diabetes } \\
\text { mellitus }\end{array}$ \\
\hline & Pharmacological & $\begin{array}{l}\text { Steriods, benzodiazepines, chlordiazepoxide, diazepam, antibiot- } \\
\text { ics, sulfonamides, opioids, cisplatinum (Jatoi 2009), analeptic } \\
\text { agent, Methyldopa, L-dopa, Dopamine }\end{array}$ \\
\hline & Psychosomatic & Anxiety, sleep deprivation, stress and fear \\
\hline
\end{tabular}




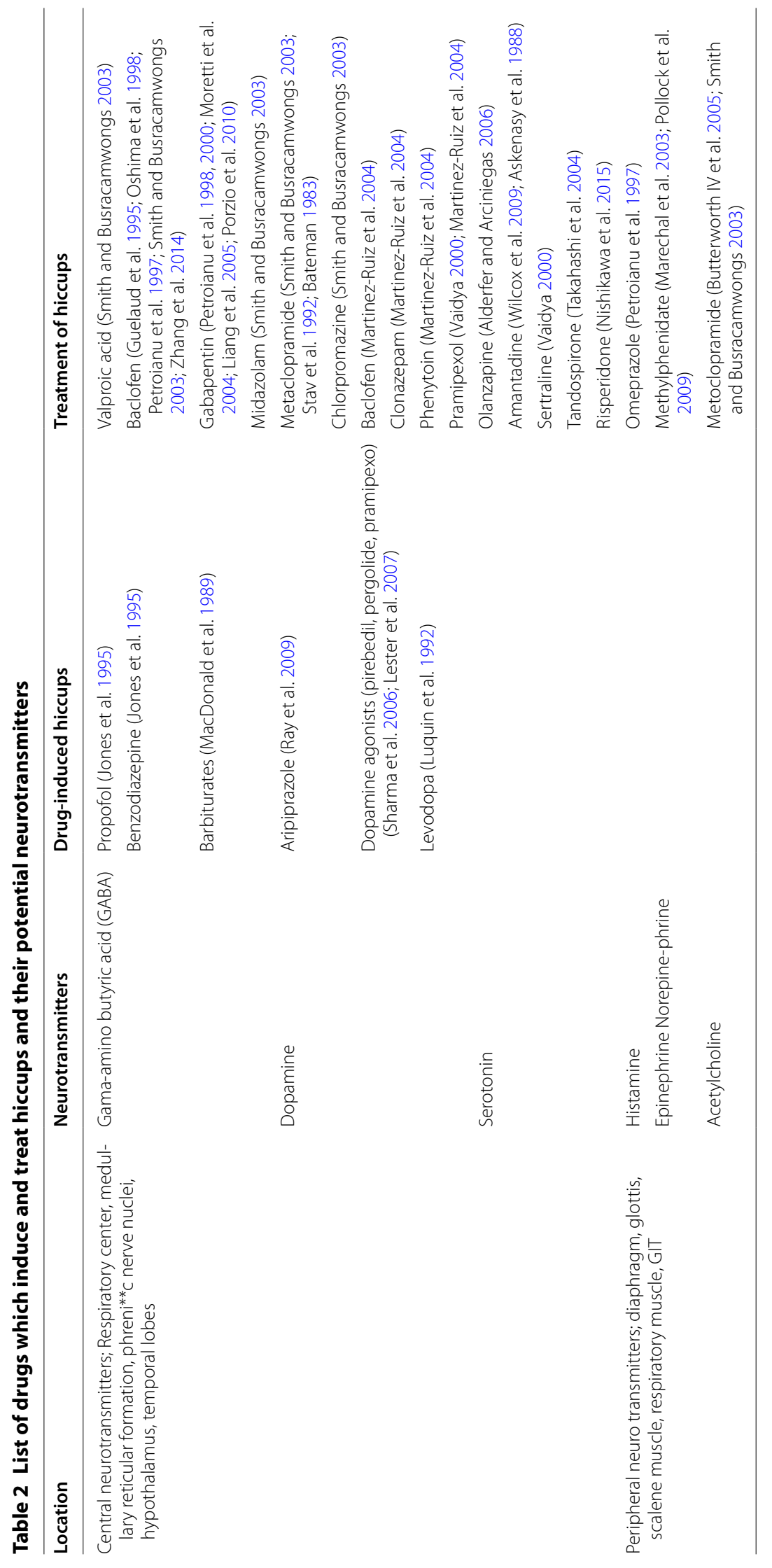


motor neurons. There are three main types of GABA receptors-GABA-A, $-\mathrm{B}$, and $-\mathrm{C}$. GABA-A are the most abundant receptors and the site of action of many neuro active drugs such as benzodiazepines, barbiturates, ethanol and volatile anesthetics (Molinoff 2011). Valproic acid enhances GABA transmission centrally (Smith and Busracamwongs 2003) and is one of the most commonly suggested therapies for hiccups. It is postulated in a study that the GABA-containing cells in the nucleus raphe are the source of GABA-ergic inhibition of the hiccup center (Musumeci et al. 2000).

\section{Dopamine}

There are many studies to support the convincing role of dopamine as the central neurotransmitter involved in hiccup pathogenesis. Dopamine is found in the brain and peripherally in the adrenal medulla, plexuses of the GI tract, and the enteric nervous system. Dopamine is an adrenergic agonist that is non-selective (Morgan et al. 2005). There are five dopamine receptor subtypes that have been delineated by pharmacological analysis that are the bases of a subtype of selective drugs. There are three major dopaminergic pathways in the central nervous system:

1. the niagrostriatal pathway which is important in Parkinson's disease;

2. the mesolimbic pathway which plays a role in psychiatric disorders; and

3. the tuberoinfundibular pathway, which is related to the regulation of the endocrine system.

Dopamine is an immediate precursor of norepinephrine. The synthesis of dopamine can be increased by giving DOPA (Smith and Busracamwongs 2003; Ashley and Krych 1995). There are many studies, in which patients have been treated successfully by using dopamine blocking drugs such as metochlopromide and chlorpromazine (Smith and Busracamwongs 2003) which supports the evidence that dopamine acts as the central neurotransmitter.

\section{5-Hydroxyl tryptamine (5HT; serotonin)}

Many studies support the role of 5HT (serotonin) as the neurotransmitter of hiccups. Serotonin is an important central nervous system neurotransmitter and a local hormone. It is also found in high concentrations in enterochromaffin cells throughout the GIT that are the site of synthesis and storage of $5 \mathrm{HT}$ from tryptophan. It regulates the smooth muscles in the GIT to increase the tone and facilitate the peristalsis via $5 \mathrm{HT} 2$ receptors (Katzung 2012). It is a powerful vasoconstrictor mainly through 5 HT2 receptor but it dilates the blood vessels of the heart and skeletal muscles (Katzung 2012). It is produced in two steps: in step 1, tryptophan in converted to $5 \mathrm{HT}$ and in the next step, the 5HT is converted to serotonin. Increasing the concentration of tryptophan in the brain can increase the high concentration of 5HT and serotonin. Drugs that increase serotonin levels were most commonly used as appetite suppressants. They regulate the smooth muscles in the GIT and cardiovascular system. There are fourteen subtypes of receptor of $5 \mathrm{HT}$ recognized. There are the $5 \mathrm{HT} 1$ subfamily and $5 \mathrm{HT} 2$ subfamilies of receptors. 5HT3 subfamilies were originally described in the periphery. There are fourteen subtypes of receptor of 5HT recognized. Cases of intractable hiccups have been successfully treated with olanzapine (Alderfer and Arciniegas 2006). Olanzapine has a complex pharmacology and its major effect is to antagonize the postsynaptic serotonergic receptors. Similarly, another case was reported describing the successful treatment of hiccups with sertraline, a selective serotonin reuptake inhibitor (SSRI), for the first time (Benowitz 2012; Vaidya 2000). In one case study, intractable hiccups were treated successfully with a tandospirone, a new anxiolytic and 5HTA1 receptor agonist (Takahashi et al. 2004). Interestingly, a case report of intractable hiccups that was refractory to the typical antipsychotic haloperidol, however, responsive to atypical antipsychotic risperidone which acts on 5HT2A, 5HT1A, 5HT1C, 5HT1D, and D2 receptors (Nishikawa et al. 2015). All these studies are evidence that serotonin is involved in the pathophysiology of hiccups.

\section{Histamine}

Histamine is produced by decarboxylation of histadine, an amino acid, by the enzyme histadine decarboxylases (Biomedical Aspects of Histamine 2011).

Histamine is released by the various triggers from mast cells and basophils and has various biological effects through four receptors H1R, H2R, H3R, H4R. Histamine causes smooth cell contractions, vasodilatation, and gastric acid secretion. Hyperhistaminemia can cause an anaphylactic reaction (Hershko et al. 2001). There is evidence for the use of $\mathrm{H} 2$-receptor blockers and proton pump inhibitors (i.e. omeprazole) for the treatment of hiccups thought to act via decreasing the input from the GIT to the hiccup center (Petroianu et al. 1997).

\section{Epinephrine and norepinephrine (NE)}

Noreepinephrine (NE) is the neurotransmitter of the post ganglionic autonomic nervous system that is involved in the reduction of gastrointestinal motility. $\mathrm{NE}$ is synthesized from tyrosine that is produced from phenyle alanine. Dopamine is converted to NE by dopamine beta hyroxylases. Norepinephrine is converted 
to epinephrine by the enzyme phenyle ethanolamine$\mathrm{N}$-methyltransferase. The action of neurotransmitter catecholamines is terminated by the re-uptake and metabolism by the enzymes monoamine oxidases (MOA) and catecolaminotransferases (COMT). The inhibitors of these enzymes are used in the treatment of Parkinson's disease. Adreno receptors have four subtypes, alpha1, alpha2, and beta1 for NE mainly and B2 is for epinephrine mainly. There are studies about the successful treatment of hiccups with methylphenidate (a psycho-stimulant) generally used in attention deficit disorders (Marechal et al. 2003; Pollock et al. 2009). The methylphenidate is considered as the receptor modulator of dopamine and norepinephrine. Therefore relationship may exist between norepinephrine and epinephrine to the pathophysiology of hiccups.

\section{Acetylcholine}

Acetylcholine is a naturally occurring neurotransmitter for the muscarinic receptors. It is a neurotransmitter of all the preganglionic autonomic fibres, most postganglionic parasympathetic, and a few post-ganglionic sympathetic fibers (Westfall and Westfall 2011). Metoclopramide, an anticholinergic, is recommended for the symptomatic relief of hiccups. There are studies that show that metoclopramide acts peripherally to reduce the intensity of esophageal contraction (Consults 2011). It has also been observed that metoclopramide have been used to treat hiccups (Smith and Busracamwongs 2003) which may explain the relation of acetylcholine as the peripheral neurotransmitter involved in the pathophysiology of hiccups.

\section{Conclusion}

Largely through case studies involving medications, we implicate the neurotransmitters involved in hiccups. The reflex arc is potentially mediated by central neurotransmitters (GABA, dopamine, and serotonin) and peripheral neurotransmitters (epinephrine, norepinephrine, acetylcholine, and histamine). Lesions across any of these neuroanatomical structures, for instance, from the brainstem down to the diaphragm, may be responsible for the development of hiccups. Further research is needed to characterize the neurotransmitters involved in hiccups for potential new therapeutic targets.

\section{Authors' contributions \\ Conceived and designed the paper: FN, HM, SEL. All authors participated in the preparation of the manuscript. All authors read and approved the final manuscript.}

\section{Author details}

1 Department of Medical Education, California University of Science and Medicine - School of Medicine, 1405 W. Valley Blvd, Suite 101, Colton, CA 92343, USA. ${ }^{2}$ Department of Neurology, California University of Science and Medicine - School of Medicine, Colton, CA, USA.

\section{Acknowledgements}

We would like to extend our thanks to the Chair, Professor and Associate Dean for Clinical Research, Department of Cellular Biology and Pharmacology Florida International University, Dr. Georg Petroianu. Without his help and guidance this review would have not been possible. It is our pleasure to convey our gratitude to him in our humble acknowledgement. Also, we wish to thank Ellen Wilkinson and Nancy Bethel of California University of Science and Medicine for their editing support, guidance, and suggestions.

\section{Competing interests}

The authors declare that they have no competing interests.

Received: 9 March 2016 Accepted: 10 August 2016

Published online: 17 August 2016

\section{References}

Alderfer BS, Arciniegas DB (2006) Treatment of intractable hiccups with olanzapine following recent severe traumatic brain injury. J Neuropsychiatry Clini Neurosci 18(4):551-552. doi:10.1176/jnp.2006.18.4.551

Ashley MJ, Krych DK (1995) Traumatic brain injury rehabilitation, 1st edn. CRCPress, Boca Raton

Askenasy JJ, Boiangiu M, Davidovitch S (1988) Persistent hiccup cured by amantadine. N Engl J Med 318(11):711. doi:10.1056/ NEJM198803173181118

Bateman DN (1983) Clinical pharmacokinetics of metoclopramide. Clin Pharmacokinet 8(6):523-529

Benowitz NL (2012) Antidepressants, general (noncyclic). In: Olson K (ed) Poisoning and drug overdose, 6th edn. McGraw-Hill Professional, New York

Biomedical Aspects of Histamine (2011). Springer Netherlands, Dordrecht

Burke AM, White AB, Brill N (1988) Baclofen for intractable hiccups. N Engl J Med 319(20):1354. doi:10.1056/NEJM198811173192016

Butterworth IV JF, Mackey DC, Wasnick JD (2005) Adjuncts to anesthesia. In: Morgan G, Mikhail M, Murray M (eds) Clinical anesthesiology, 4th edn. McGraw-Hill, New York

Consults D (2011) Hiccups_etilogy and treatment. http://hslibrary.ucdenver. edu/. Accessed Sept 2011

Cymet TC (2002) Retrospective analysis of hiccups in patients at a community hospital from 1995-2000. J Natl Med Assoc 94(6):480-483

Davis JN (1970) An experimental study of hiccup. Brain 93(4):851-872

Dobelle WH (1999) Use of breathing pacemakers to suppress intractable hiccups of up to thirteen years duration. ASAIO J 45(6):524-525

Friedman NL (1996) Hiccups: a treatment review. Pharmacotherapy 16(6):986-995

Gilson I, Busalacchi M (1998) Marijuana for intractable hiccups. Lancet 351(9098):267. doi:10.1016/S0140-6736(05)78270-2

Guelaud C, Similowski T, Bizec JL, Cabane J, Whitelaw WA, Derenne JP (1995) Baclofen therapy for chronic hiccup. Eur Respir J 8(2):235-237

Hansen BJ, Rosenberg J (1993) Persistent postoperative hiccups: a review. Acta Anaesthesiol Scand 37(7):643-646

Hershko AY, Dranitzki Z, Ulmanski R, Levi-Schaffer F, Naparstek Y (2001) Constitutive hyperhistaminaemia: a possible mechanism for recurrent anaphylaxis. Scand J Clin Lab Invest 61 (6):449-452

Howes D (2012) Hiccups: a new explanation for the mysterious reflex. BioEssays 34(6):451-453. doi:10.1002/bies.201100194

Jatoi A (2009) Palliating hiccups in cancer patients: moving beyond recommendations from Leonard the lion. J Support Oncol 7(4):129-130

Jones MV, Harrison NL, Pritchett DB, Hales TG (1995) Modulation of the GABAA receptor by propofol is independent of the gamma subunit. J Pharmacol Exp Ther 274(2):962-968

Katzung BG (2012) Histamine, serotonin, and the ergot alkaloids. In: Katzung BG, Masters SB, Trevor AJ (eds) Basic and clinical pharmacology. McGrawHill, New York

Launois S, Bizec JL, Whitelaw WA, Cabane J, Derenne JP (1993) Hiccup in adults: an overview. Eur Respir J 6(4):563-575

Lester J, Raina GB, Uribe-Roca C, Micheli F (2007) Hiccup secondary to dopamine agonists in Parkinson's disease. Mov Disord 22(11):1667-1668. doi:10.1002/mds.21583

Lewis JH (1985) Hiccups: causes and cures. J Clin Gastroenterol 7(6):539-552 
Liang C, Tsai K, Hsu M (2005) Gabapentin therapy for persistent hiccups and central post-stroke pain in a lateral medullary infarction-two case reports and literature review. Tzu Chi Med J 17:365-368

Luquin MR, Scipioni O, Vaamonde J, Gershanik O, Obeso JA (1992) Levodopainduced dyskinesias in Parkinson's disease: clinical and pharmacological classification. Mov Disord 7(2):117-124. doi:10.1002/mds.870070204

MacDonald RL, Rogers CJ, Twyman RE (1989) Barbiturate regulation of kinetic properties of the GABAA receptor channel of mouse spinal neurones in culture. J Physiol 417:483-500

Marechal R, Berghmans T, Sculier P (2003) Successful treatment of intractable hiccup with methylphenidate in a lung cancer patient. Support Care Cancer 11(2):126-128. doi:10.1007/s00520-002-0411-y

Martinez-Ruiz M, Fernandez Riestra Fde A, Quesada Rubio R (2004) Pramipexole for intractable hiccups. Med Clin 123(17):679

Molinoff PB (2011) Neurotransmission and the central nervous system. In: The pharmacological basis of therapeutics, 12th edn. McGraw-Hill Professional, New York

Moretti R, Torre P, Antonello RM, Ukmar M, Cazzato G, Bava A (2004) Gabapentin as a drug therapy of intractable hiccup because of vascular lesion: a three-year follow up. Neurologist 10(2):102-106

Moretto EN, Wee B, Wiffen PJ, Murchison AG (2013) Interventions for treating persistent and intractable hiccups in adults. Cochrane Database Syst Rev. doi:10.1002/14651858.CD008768.pub2

Morgan JGE, Mikhail MS, Murray MJ (2005) Adrenergic Agonists and Antagonists. In: Morgan G, Mikhail M, Murray M (eds) Clinical Anesthesiology, 4th edn. McGraw-Hill, New York

Musumeci A, Cristofori L, Bricolo A (2000) Persistent hiccup as presenting symptom in medulla oblongata cavernoma: a case report and review of the literature. Clin Neurol Neurosurg 102(1):13-17

Nishikawa T, Araki Y, Hayashi T (2015) Intractable hiccups (singultus) abolished by risperidone, but not by haloperidol. Ann Gen Psychiatry 14:13. doi:10.1186/s12991-015-0051-5

Oshima T, Sakamoto M, Tatsuta H, Arita H (1998) GABAergic inhibition of hiccup-like reflex induced by electrical stimulation in medulla of cats. Neurosci Res 30(4):287-293

Peleg R, Peleg A (2000) Case report: sexual intercourse as potential treatment for intractable hiccups. Can Fam Physician Medecin de famille canadien 46:1631-1632

Petroianu G, Hein G, Petroianu A, Bergler W, Rufer R (1997) Idiopathic chronic hiccup: combination therapy with cisapride, omeprazole, and baclofen. Clin Ther 19(5):1031-1038

Petroianu G, Hein G, Petroianu A, Bergler W, Rufer R (1998) ETICS study: empirical therapy of idiopathic chronic singultus. Z Gastroenterol 36(7):559-566

Petroianu G, Hein G, Stegmeier-Petroianu A, Bergler W, Rufer R (2000) Gabapentin "add-on therapy" for idiopathic chronic hiccup (ICH). J Clin Gastroenterol 30(3):321-324
Pollock BG, Semla TP, Forsyth CE (2009) Psychoactive drug therapy. In: Halter JB, Ouslander JG, Tinetti ME, Studenski S, High KP, Asthana S (eds) Hazzard's geriatric medicine and gerontology, 6th edn. McGraw-Hill, New York

Porzio G, Aielli F, Verna L, Aloisi P, Galletti B, Ficorella C (2010) Gabapentin in the treatment of hiccups in patients with advanced cancer: a 5-year experience. Clin Neuropharmacol 33(4):179-180. doi:10.1097/ WNF.0b013e3181de8943

Ray P, Zia UI Haq M, Nizamie SH (2009) Aripiprazole-induced hiccups: a case report. Gen Hosp Psychiatry 31(4):382-384. doi:10.1016/j. genhosppsych.2008.09.014

Rodwell VW (2012) Conversion of amino acids to specialized products. In: Rodwell V, Bender D (eds) Harper's illustrated biochemistry. McGraw-Hill, New York

Rousseau P (1995) Hiccups. South Med J 88(2):175-181

Sharma P, Morgan JC, Sethi KD (2006) Hiccups associated with dopamine agonists in Parkinson disease. Neurology 66(5):774. doi:10.1212/01. wnl.0000201267.78431.f0

Smith HS, Busracamwongs A (2003) Management of hiccups in the palliative care population. Am J Hosp Palliat Care 20(2):149-154

Stav A, Weksler N, Berman M, Lemberg L, Ribak L, Segal A, Machamid E, Ovadia L, Sternberg A (1992) Premedication with metoclopramide decreases the frequency of methohexital induced hiccup. J Anesth 6(1):17-20. doi:10.1007/s0054020060017

Steger M, Schneemann M, Fox M (2015) Systemic review: the pathogenesis and pharmacological treatment of hiccups. Aliment Pharmacol Ther 42(9):1037-1050. doi:10.1111/apt.13374

Takahashi T, Murata T, Omori M, Tagaya M, Wada Y (2004) Successful treatment of intractable hiccups with serotonin (5-HT)1A receptor agonist. J Neurol 251(4):486-487. doi:10.1007/s00415-004-0377-4

Todisco T, Todisco C, Bruni L, Donato R (2004) Chin stimulation: a trigger point for provoking acute hiccups. Respiration 71(1):104. doi:10.1159/000075661

Twycross R, Wilcock A, Charlesworth S, Dickman A (2002) Palliative care formulary, 2nd edn. Radcliffe Medical Press, Oxford

Vaidya V (2000) Sertraline in the treatment of hiccups. Psychosomatics 41(4):353-355. doi:10.1176/appi.psy.41.4.353

Westfall TC, Westfall DP (2011) Neurotransmission: the autonomic and somatic motor nervous systems. In: Brunton L, Chabner B (eds) Goodman and Gilman's the pharmacological basis of therapeutics, 12th edn. McGrawHill, New York

Wilcox SK, Garry A, Johnson MJ (2009) Novel use of amantadine: to treat hiccups. J Pain Symp Manag 38(3):460-465. doi:10.1016/j. jpainsymman.2008.10.008

Zhang C, Zhang R, Zhang S, Xu M, Zhang S (2014) Baclofen for stroke patients with persistent hiccups: a randomized, double-blind, placebo-controlled trial. Trials 15:295. doi:10.1186/1745-6215-15-295

\section{Submit your manuscript to a SpringerOpen ${ }^{\odot}$ journal and benefit from:}

- Convenient online submission

- Rigorous peer review

- Immediate publication on acceptance

- Open access: articles freely available online

- High visibility within the field

- Retaining the copyright to your article

Submit your next manuscript at springeropen.com 